UII norden

\title{
Plastic sorting at recycling centres
}

\author{
Background report
}

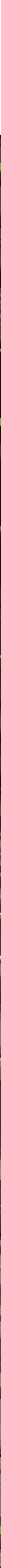



4 norden 



\section{Plastic sorting at recycling centres}

Background report

Lizzi Andersen 
Plastic sorting at recycling centres

Background report

Lizzi Andersen

ISBN 978-92-893-3958-2 (PRINT)

ISBN 978-92-893-3960-5 (PDF)

ISBN 978-92-893-3959-9 (EPUB)

http://dx.doi.org/10.6027/TN2015-511

TemaNord 2015:511

ISSN 0908-6692

(C) Nordic Council of Ministers 2014

Layout: Hanne Lebech

Cover photo: Signelements

Print: Rosendahls-Schultz Grafisk

Printed in Denmark

This publication has been published with financial support by the Nordic Council of Ministers. However, the contents of this publication do not necessarily reflect the views, policies or recommendations of the Nordic Council of Ministers.

\section{www.norden.org/en/publications}

Nordic co-operation

Nordic co-operation is one of the world's most extensive forms of regional collaboration, involving Denmark, Finland, Iceland, Norway, Sweden, and the Faroe Islands, Greenland, and Åland.

Nordic co-operation has firm traditions in politics, the economy, and culture. It plays an important role in European and international collaboration, and aims at creating a strong Nordic community in a strong Europe.

Nordic co-operation seeks to safeguard Nordic and regional interests and principles in the global community. Common Nordic values help the region solidify its position as one of the world's most innovative and competitive.

\section{Nordic Council of Ministers}

Ved Stranden 18

DK-1061 Copenhagen K

Phone (+45) 33960200

www.norden.org 


\section{Content}

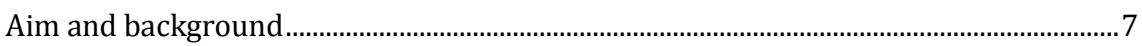

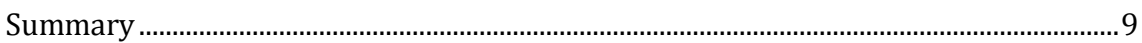

1. Introduction........................................................................................................................ 11

1.1 Methodology for the development of the guideline....................................... 12

1.2 Reference group..................................................................................................... 12

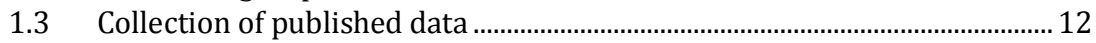

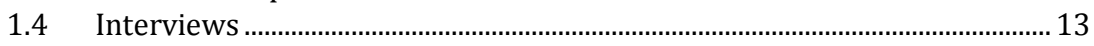

1.5 Workshops ........................................................................................................... 13

1.6 Assessment of data from stakeholders and projects .......................................... 14

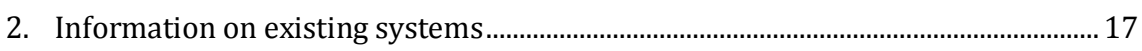

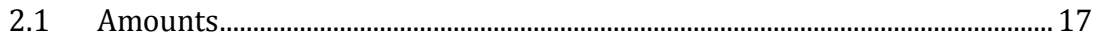

2.2 Plastic waste based on applications and post-consumer waste

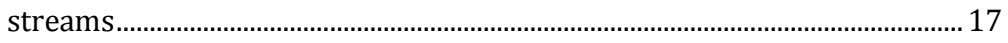

2.3 Collection systems at the recycling centres .................................................... 19

3. Market opportunities .................................................................................................... 29

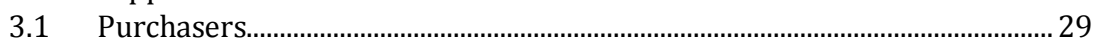

3.2 Fractions currently sorted at recycling centres.............................................. 30

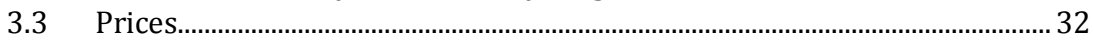

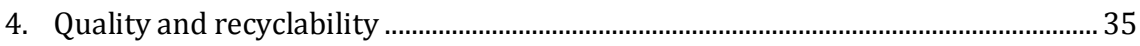

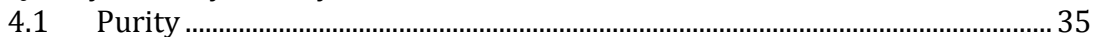

4.2 Recyclability of the plastic could be more transparent ................................... 36

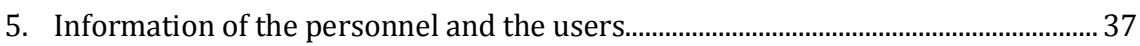

5.1 Personnel as communicators .......................................................................... 37

5.2 Information at the recycling centre ............................................................... 37

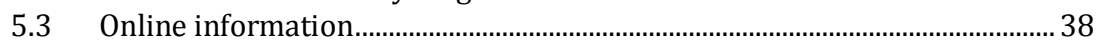

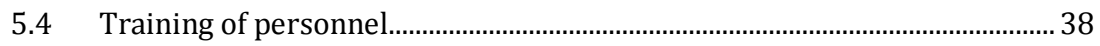

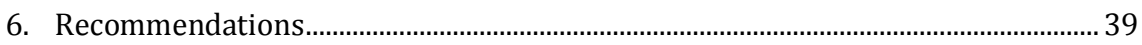

6.1 Information and dialogue with purchasers....................................................... 39

6.2 Dialog between recycling centres..................................................................... 40

6.3 Dissemination and further work..................................................................... 40

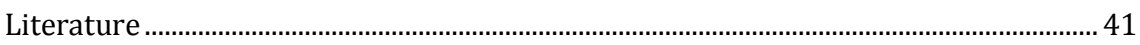

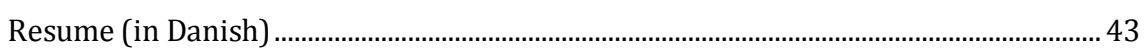

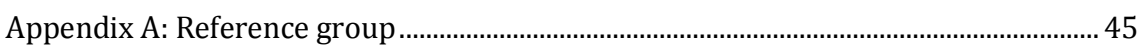

Appendix B: Questionnaire.............................................................................................. 47

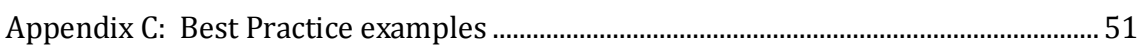

Göteborg - Kretsloppsparken Alelyckan, Sweden ......................................................51

Sønderborg Forsyning - Skodsbøl genbrugsstation, Denmark................................ 53

Vestforbrænding - Ballerup genbrugsstation, Denmark ......................................... 56 



\section{Aim and background}

This report is a background report for the "Guideline of plastic sorting at recycling centres". The aim of the guideline is to give assistance to the choices made by the management of the recycling centres with the purpose of collecting plastic of better qualities and in greater quantities. The collection at recycling centres will often be part of a larger system for collection of waste plastic, e.g. often supplementing kerbside collection of plastic materials. The overall ambition is that most of the recyclable plastic is sorted out for recycling. The guide addresses both larger, advanced recycling centres and smaller recycling centres.

The guide is part of the Nordic Prime Minister's initiative, The Nordic Region - leading in green growth. It is financed by the Nordic Waste Group under the Nordic Council of Ministers, acknowledging that the present situation in the Nordic countries is quite different with respect to how the collection of plastic waste is organised. It is based on the collection of information and practical experience through interviews with a number of operators within the value chain related to collection, sorting and recycling of plastic from recycling centres in the Nordic countries supplemented with sorting trials. 



\section{Summary}

The background report describes the methodology used in preparing the guideline; that is the gathering of experiences and opinions on collection of plastic at recycling centres. This is carried out through interviews with recycling centres, purchasers and recyclers of waste plastics. The interviews have been supplemented by a literature review, two sorting trials, and a discussion of the findings at workshops for the stakeholders in November 2013 and October 2014 respectively.

The background report first presents information from existing systems and the stakeholders that can be used directly at the recycling centre in their decision process: How the different plastic types can be collected and handled at the recycling centre, how the choice of collection at the recycling centre has to be thought into the existing waste system, and how the plastic containing hazardous substances should be avoided when recycling (Chapter 3).

Secondly, the report describes the importance of understanding and communicating with the purchasers about the expectations on purity of the plastic from the recycling centre, and the traceability of the plastic once it is delivered to the purchaser and moving further down the value chain (Chapter 4 and 5).

Thirdly, the opinions and information on the importance of information to both the personnel and the users are presented (Chapter 6). Finally, some recommendations regarding more knowledge sharing among recycling centres and purchasers are put forward (Chapter 7).

The appendices contain information about the reference group connected to the project, the questions asked when collecting information from stakeholders, examples of best practice, and finally a list of literature and other information sources used in the project.

The report is part of the Nordic Prime Minister's overall green growth initiative, The Nordic Region - leading in green growth. Read more in the web magazine "Green Growth the Nordic Way" at www.nordicway.org or at www.norden.org/greengrowth 



\section{Introduction}

Under the auspices of the Nordic Council of Ministers, the Nordic Waste Group has initiated three projects focusing on the improvement of the quantity and quality of plastic from waste. The projects are part of the Nordic Prime Minister's green growth initiative, The Nordic Region leading in green growth. The initiative identifies eight priorities aimed at greening the Nordic economies, one of which is to develop innovative technologies and methods for waste treatment.

One of these projects focuses on the development and testing of a guideline for plastic sorting at recycling centers.

The aim of the project is to develop a plastic sorting guide for Nordic recycling centres based on practical experiences that will encourage municipalities and private businesses to implement better solutions and better service. The guide shall include brief texts/instruction and some background information to the proposals that are made.

The Nordic Waste Group has required that the project is divided into two phases:

- Part 1: Fact finding, assessment and suggestion for sorting guide.

- Part 2: Test programme and testing of guide, final guide, including dissemination and education plan.

It has been agreed with the Nordic Waste Group that the reporting of the project is divided into a background report describing the overall methodology used in the project and background information collected and the guideline as such. This report is the background report, including the dissemination and education plan.

The methodology used for the development of the guideline is described in Chapter 2, while one of the results, the compiling of information and data from recycling centres and projects is described in Chapter 3. Information regarding market opportunities is compiled in Chapter 4, while data on quality and recyclability is compiled in Chapter 5. Chapter 6 contains suggestions received with respect to information of users and training of personnel, while Chapter 7 contains recommendation based on issues raised by the interviewed recycling centres, etc. 


\subsection{Methodology for the development of the guideline}

This chapter describes the overall methodology for collecting data and opinions relevant as a basis for the development of the draft guideline. The information has been collected through:

- the reference group set up as a sparring partner for the project

- gathering of information included in other reports focusing on recycling of plastic waste, primarily at recycling centres

- interviews with other recycling centres and stakeholders

- the workshops held to discuss results from all three plastic waste projects

- sorting trials.

\subsection{Reference group}

At the beginning of the project a number of stakeholders were asked to become members of a reference group, which would entail being part of the group of stakeholders being interviewed, delivering of readily available data relevant for the project, commenting of the issues to be included in the guideline and the guideline itself. Further members were included during Part 1 to ensure as broad coverage as possible (and manageable). A list of the members included in the reference group is included in Appendix A.

\subsection{Collection of published data}

Information on plastic collected at recycling centres is not common in published literature. A few Nordic reports exist that address mainly description of overall systems for plastic collection in the country, estimates of plastic waste categories, information on and suggestions for sorting guides.

This information has been compiled and made part of the basis for the guideline together with information collected on specific systems in a number of municipalities, where available.

In general, not much information about e.g. amounts and costs is available through published data. 
There is information given on the internet on available systems for specific municipalities and/or waste management companies, but not all municipalities make such information available and a review of information from all Nordic municipalities is beyond what is possible within this project.

\subsection{Interviews}

Data regarding the existing systems have been collected from single recycling centres as well as from whole waste management companies depending on the availability of data. The data does not cover whole countries, but examples from all Nordic countries are included.

Data for assessment of the market opportunities has also been gathered from the reference group and other relevant stakeholders (dealers, recycling companies, plastic producers, stakeholder organisations etc.).

The data collection has been based on questionnaires used as the basis for telephone interviews with some degree of follow-up with further questions and the gathering of specific data. The questionnaire used is shown in Appendix B. In total 24 stakeholders have been interviewed. The results of this data collection are presented in the latter chapters of this report.

Apart from specific information on collected fractions, purchasers, amounts and costs, information materials etc. the interviewees were asked about which issues they considered to be the more important when deciding how to increase the quantity and quality of plastic waste collected for recycling at the recycling centres, and which issues they themselves had found inhibitory when deciding on how to proceed. The answers to these questions have been essential for how the draft guideline has been set up.

\subsection{Workshops}

Based on the collected information and statements, a number of issues to be discussed directly at the workshop held in Oslo, 11th November 2013:

- How many fractions/types of plastic should be collected at the rec. centres?

O One mixed plastic fraction or separate streams? User friendliness vs. costs. 
- Market transparency?

- Who receives which plastic types?

- What are the quality requirements and costs/prices?

- Relation between quality and costs.

- Increased dialogue between rec. centres and purchasers.

- Information and communication to users are important.

- Showing the importance of the sorting, through training and study tours for personnel.

- How to test the draft guideline?

The comments to these questions and general input received at the workshop have also been essential for the way the draft guideline has been set up.

At the second workshop in Copenhagen, 9th October 2014, the overall findings from the project was presented, and general issues discussed, especially at the roundtable parts of the workshop. This has been taken into account in the final version of the guideline.

\subsection{Assessment of data from stakeholders and projects}

Information has been collected also from a number of recycling centres that have fairly advanced systems both with respect to the number of fractions they handle, the pre-sorting and/or compaction options that are used, the information for the public and the training of the personnel. Nevertheless, a generalised best practice is not described, since there are both differences in the general organisational set-up between the Nordic countries, the types of plastic that available purchasers will accept within a feasible distance, what is doable for a small, relatively remote community and a large city. This means that the best solution for increasing of both the overall quality and quality of the plastic collected at a given recycling centre is very much dependent on the local setting. ${ }^{1}$ This is thus the basis for the suggestions given in the guideline. Along these lines, the guideline includes a description of the key

\footnotetext{
${ }^{1}$ And will also change over time as new options develop with respect to e.e. local purchasers and soting options for specific fractions, use in new products, etc.
} 
decisions to be made in the process of implementing plastic collection at recycling centres.

As a basis for this, this background report compiles information on all the fractions that have been collected at one or more of the recycling centres from where data has been gathered (either through interviews or through other kinds of public reporting found) together with information on equipment used, available purchasers etc. in the following chapters. Also all suggestions with respect to information for the public and training of personnel are presented.

\section{Sorting trials and testing}

It was originally the intention to carry out tests at potential recycling centres on how the guideline would function in practice. It turned out not to be possible to find a recycling centre in the phase where they were planning to start or expand their sorting of plastic at the time, where the testing should have taken place. Instead we have obtained comments on the guideline from a number of recycling centres that have different experiences with respect to sorting of plastic. Taking this into account together with the fact that the recommendations in the guideline was from the beginning based on experience from a number of recycling centres with relatively divers setting, it was instead chosen to carry out trials on how the recommendations in the test guideline with respect to sorting of plastic potentially containing hazardous substances would work out in practice. Little information is in general available on this issue. The sorting trials were carried out at ØRAS in Norway and the municipality of Stockholm respectively. 



\section{Information on existing systems}

This chapter describes the data available concerning the present systems and in some cases, the considerations made with respect to relevant improvements.

In general, data regarding collected amounts and the related costs of the operations are not available in sufficient degree to generalise. Often the interviewed stakeholders were not willing to publish data on specific costs, or costs related to amounts calculated where not directly available. Data regarding collected amounts often only cover quite short time periods, since many of the systems have only been put in place recently.

\subsection{Amounts}

During the analysis of the interviews, it has become clear that data on the amounts of the specific plastic fractions are important. As mentioned, not much detailed information is available from the recycling centres. The best available overall data at present seem to be the data presented in the report "Resource efficient recycling of plastic and textile waste". The data on the plastic amounts relevant for the recycling centres are presented in the following. The data is also included in the guideline as an appendix.

\subsection{Plastic waste based on applications and post- consumer waste streams}

To give an idea about the amounts a recycling centre can expect, an overview of the plastic amounts is presented in the two tables below. The total amounts of plastic are the same in the two figures. First, they are given per application (Table 1) and secondly as post-consumer waste in the different waste streams (Table 2). 


\begin{tabular}{|c|c|c|c|c|c|c|c|}
\hline & DK & $\mathbf{N}$ & $\mathbf{s}$ & SF & Total & $\begin{array}{r}\% \\
\text { Nordic }\end{array}$ & $\begin{array}{r}\% \\
\text { Europe }\end{array}$ \\
\hline Packaging & 207 & 149 & 217 & 116 & 689 & 61 & 62 \\
\hline Building / Construction & 17 & 12 & 15 & 12 & 56 & 5 & 6 \\
\hline Automotive & 11 & 11 & 18 & 10 & 50 & 4 & 5 \\
\hline WEEE & 17 & 18 & 31 & 15 & 81 & 7 & 5 \\
\hline Housewares, leisure, sports & 10 & 10 & 15 & 11 & 46 & 4 & 3 \\
\hline Agriculture & 16 & 12 & 17 & 10 & 55 & 5 & 5 \\
\hline Other (Furniture, etc.) & 31 & 30 & 51 & 34 & 146 & 13 & 14 \\
\hline Total & 310 & 240 & 363 & 208 & 1.121 & 100 & 100 \\
\hline Kg/capita & 56 & 48 & 39 & 39 & 45 & & \\
\hline
\end{tabular}

The plastic applications that most likely will end in the plastic fractions at the recycling centres are housewares, leisure articles, sports goods, and the part of the furniture, which is made mostly of plastic, such as plastic garden furniture, and to some extent film from agriculture. Some application types will not end up at the recycling centres, e.g. plastic packaging in Norway and Sweden, which will be collected through the specific system set up for collection of packaging waste. Plastic materials in WEEE will in principle be collected as WEEE and first later through the recycling processes be sorted in to a specific plastic fraction. Likewise, automotive plastic will primarily be handled as required in the End of Life Vehicles Directive, though some Danish recycling centres collect car bumpers. One should be aware that also plastic applications for commercial use is included in the figures given, and this stream will most likely not end up at the recycling centres.

How the plastic materials are distributed into the different waste stream is presented in Table 2 .

2 Resorece efficient recycling of plastic and textile waste, 2012, eferring to PlasticEurope, EuPC, EuPR, EPRO and Consultic: Plastics - The Facts 2011 - An analysis of European plastics production, demand and recovery for 2010 . 


\begin{tabular}{|c|c|c|c|c|c|c|}
\hline & DK & $\mathbf{N}$ & $\mathbf{s}$ & SF & Total & $\%$ \\
\hline Residual household waste & 158 & 69 & 124 & 89 & 440 & 39 \\
\hline $\begin{array}{l}\text { Separate collection from hh by municipali- } \\
\text { ties (non-packaging) }\end{array}$ & 1 & 0 & 0 & 0 & 1 & - \\
\hline Sales packaging waste collected & 13 & 22 & 61 & 15 & 111 & 10 \\
\hline WEEE waste collection & 15 & 17 & 29 & 11 & 72 & 6 \\
\hline $\begin{array}{l}\text { Municipal waste generated by commercial } \\
\text { activities }\end{array}$ & 31 & 40 & 40 & 36 & 147 & 13 \\
\hline Commercial \& Industrial waste & 13 & 21 & 13 & 15 & 62 & 6 \\
\hline Commercial packaging waste collected & 41 & 32 & 40 & 14 & 127 & 11 \\
\hline ELV, incl. auto-shredded waste & 10 & 9 & 15 & 8 & 42 & 4 \\
\hline Other recycling systems & 11 & 19 & 17 & 5 & 52 & 5 \\
\hline Total & 310 & 240 & 363 & 208 & 1,121 & 100 \\
\hline
\end{tabular}

Table 2 shows a marked difference between the amount of plastic in residual household waste for Denmark versus Sweden and Norway: Denmark has the highest amount of plastics in the residual household waste compared to Sweden and Norway, and the lowest amount of plastic collected through the packaging waste streams. This is most likely due to the very different implementation of the packaging directive in the three countries, where Norway and Sweden have established specific take back organisations with a specific collection scheme, which is not the case in Denmark.

\subsection{Collection systems at the recycling centres}

The collection systems at the recycling centres and the setup have been registered through the interviews with the municipalities and recycling centres. In Table 3, the fractions collected are listed along with the collection material used to collect them and comments on pros and cons have been added.

\footnotetext{
${ }^{3}$ Resource efficient recycling of plastic and textile waste. Preliminary report prepared for the Nordic Council of Ministers. Project number: 2012.05.21, Date 7th February 2013.
} 
Table 3. Collection material registered during the interviews with the municipalities and the waste management companies

\begin{tabular}{|c|c|c|}
\hline Fraction & Collection material & Comments \\
\hline $\begin{array}{l}\text { Bottles (PET) clear } \\
\text { (Polyethylene terephthalate (1)) }\end{array}$ & $\begin{array}{l}\text { Closed container with a lid that only } \\
\text { allows bottle size plastic to get through }\end{array}$ & $\begin{array}{l}\text { + Results in a clean fraction } \\
\text { - Time consuming for users }\end{array}$ \\
\hline $\begin{array}{l}\text { Car bumpers } \\
\text { (Polyethylene among others) }\end{array}$ & $\begin{array}{l}\text { Tip container }->\text { sorted and reloaded } \\
\text { into }->\text { large container }\end{array}$ & $\begin{array}{l}\text { + Makes it possible to sort and check } \\
\text { fraction } \\
\text { - Time consuming for personnel }\end{array}$ \\
\hline $\begin{array}{l}\text { Buckets, etc. (mix - clean and without } \\
\text { hazardous symbols) (High Density } \\
\text { Polyethylene (2)) }\end{array}$ & $\begin{array}{l}200 \mathrm{~L} \text { big bags } \\
\text { Wire cages } \\
\text { Container }\end{array}$ & \\
\hline DVD and CD (Polycarbonate) & 200 L big bags & \\
\hline $\begin{array}{l}\text { EPS } \\
\text { (Expanded Polystyrene, } \\
\text { e.g.. Flamingo }{ }^{\oplus} \text { ) }\end{array}$ & Container & $\begin{array}{l}\text { Problematic if compacted because } \\
\text { EPS is easily crushed into small bits } \\
\text { and spread uncontrollably }\end{array}$ \\
\hline $\begin{array}{l}\text { Foil - clear } \\
\text { (Low Density Polyethylene (4), Linear } \\
\text { Low Density Polyethylene (4), } \\
\text { High Density Polyethylene (2)) }\end{array}$ & $\begin{array}{l}200 \mathrm{~L} \text { big bags -> compacted } \\
660 \mathrm{~L} \text { big bags } \\
\text { Closed container with doors on the } \\
\text { side, possible to open if larger plastic } \\
\text { pieces are received }\end{array}$ & $\begin{array}{l}\text { + Minimises transport volume } \\
\text { - Rust in an outdoor compactor can } \\
\text { discolour clear foil, reducing the value }\end{array}$ \\
\hline $\begin{array}{l}\text { Foil coloured } \\
\text { (Low Density Polyethylene (4), Linear } \\
\text { Low Density Polyethylene (4), } \\
\text { High Density Polyethylene (2)) }\end{array}$ & $\begin{array}{l}200 \mathrm{~L} \text { big bags -> compressed } \\
\text { Closed container with doors on the } \\
\text { side, possible to open if larger plastic } \\
\text { pieces are received }\end{array}$ & $\begin{array}{l}\text { + Minimises transport volume } \\
+ \text { More user friendly }\end{array}$ \\
\hline $\begin{array}{l}\text { Foil - mixed both clear and coloured } \\
\text { (Low Density Polyethylene (4), Linear } \\
\text { Low Density Polyethylene (4), } \\
\text { High Density Polyethylene (2)) }\end{array}$ & $\begin{array}{l}\text { Container } \\
\text { Closed container with doors on the } \\
\text { side, possible to open if larger plastic } \\
\text { pieces are received. }\end{array}$ & + More user friendly \\
\hline $\begin{array}{l}\text { Garden furniture (plastic) } \\
\text { (Polypropylene (5)) }\end{array}$ & $\begin{array}{l}\text { Container open at the end so it is } \\
\text { possible to walk in with the garden } \\
\text { furniture. }\end{array}$ & + More user friendly \\
\hline $\begin{array}{l}\text { Hard plastic (buckets, boxes, toys) } \\
\text { incl. PVC (High Density Polyethylene } \\
\text { (2), Polyester Terephthalate (1), } \\
\text { Polypropylene (5), Polystyrene (6)) }\end{array}$ & $\begin{array}{l}\text { Tip container }->\text { sorted and reloaded } \\
\text { into }->\text { container } \\
\text { Container } \\
\text { Wire cages }\end{array}$ & $\begin{array}{l}\text { + Results in a clean fraction } \\
\text { - Time consuming for users }\end{array}$ \\
\hline $\begin{array}{l}\text { Hard plastic from packaging (High } \\
\text { Density Polyethylene (2), Polyester } \\
\text { Terephthalate (1), Polypropylene (5), } \\
\text { Polystyrene (6)) }\end{array}$ & Container & \\
\hline $\begin{array}{l}\text { Mixed plastic fraction, all plastic incl. } \\
\text { PVC (all) }\end{array}$ & Container & \\
\hline $\begin{array}{l}\text { Plastic packaging plastic (producer } \\
\text { responsibility materials) } \\
\text { (High Density Polyethylene (2), } \\
\text { Polyester Terephthalate (1), Polypro- } \\
\text { pylene (5), Polystyrene (6)) }\end{array}$ & $\begin{array}{l}\text { Container } \\
\text { FTI container }\end{array}$ & \\
\hline $\begin{array}{l}\text { Plastic crates for milk or bread (High } \\
\text { Density Polyethylene (2)) }\end{array}$ & $\begin{array}{l}\text { Cages delivered by the original user of } \\
\text { the crates }\end{array}$ & \\
\hline PVC (Hard), (Polyvinyl Chloride (3)) & Container, $11 \mathrm{~m}^{3}$ container & \\
\hline
\end{tabular}


Some of the issues that have been mentioned by the interviewees for setting up an efficient and successful collection system for plastic at the recycling centres are:

- The space available for plastic collection at the recycling centre.

- The possibilities for establishing of an intuitive and user-friendly setup.

In the following three main findings with regard to these issues are listed.

\section{Reloading from smaller containers or big bags into larger containers}

The advantages of reloading the plastic is that one can make room for the collection of more (and thus cleaner) fractions and thereby receive a better price. Another advantage is that smaller fractions in big bags can be grouped together in containers during storage and transport reducing the need for storage space, and making transport easier. The disadvantage is the extra handling of the plastic by the personnel, since they have to both sort the plastic and empty the smaller containers or big bags more often.

\section{Compaction and shredding}

To reduce the volume of the plastic, some recycling centres use compaction or shredding equipment. The advantage is the reduction in transport costs and in the area needed for stocking. However, compaction and shredding can cause problems:

- Hard plastic can splinter into so small pieces that the sorting facility cannot sort out (unless flake sorting is used).

- If the soft plastic is compacted too much, it can be difficult to separate the plastic again at the sorting facility.

- Clear foil can be miscoloured by rust form the compactor reducing its value.

- EPS can be difficult to compact, because it is easily shredded into small pieces that are difficult to keep together. It is possible to compact EPS by a factor 20 .

- For especially larger pieces of plastic it can be an advantage to shred the plastic. Before shredding it is important to have a dialog with the purchaser about which sizes they can handle at their sorting facility. 
Finally, compaction is an extra cost, which has to be justified by lower transportation costs.

\section{Designing the container to improve quality}

To increase the purity of the plastic fractions some municipalities have designed the opening in the different containers for plastic waste, so that only certain sizes of material can enter. This has - according to the recycling centres - improved the purity of the plastic waste collected. The disadvantage is that it gets more complicated for the users to sort the plastic waste they bring to the recycling centre, and therefore the municipality experienced a drop in the overall collected amounts.

\section{Storing the plastic}

Rain does not affect the quality of plastics; however, UV light does degrade the physical and chemical structure of most plastics. The effect of UV degradation varies according to the virgin polymer, therefore if plastics are to be stored outside, they should be protected (see Table 4). To avoid contamination by dust and dirt, plastics can be stored on clean concrete floors; storage of the material on pallets can also reduce contamination. Where plastics are to be stored indoors, fire-safety and prevention systems should be installed. Plastic is flammable and while it is difficult to ignite baled plastics; it is much easier for non-baled material. As such, these considerations must be integrated into the planning stages of storage areas.

Table 4. Storability of different plastic polymers

\begin{tabular}{ll}
\hline Resin/Virgin Polymer & Maximum Unprotected Outdoor \\
\hline PET & 6 months \\
HDPE & 1 month \\
PVC & 6 months \\
LDPE & 1 month \\
PP & 1 month \\
PS & 6 months \\
PTFE & Indefinitely \\
\hline
\end{tabular}

\subsubsection{Collected amounts}

The existing collection systems for bulky waste plastic at recycling centres in the Nordic countries varies with respect to a range of parameters. However, the table below shows the findings for collected amounts of hard bulky waste plastic at recycling stations per inhabitant (catchment area covered by the recycling centre) per year. 
Table 5. Collected yearly amounts of hard bulky waste plastic from different recycling centres in the Nordic countries

\begin{tabular}{lrrrl}
\hline Location & $\mathbf{t} / \mathbf{y r}$ & Population & $\mathbf{k g / i n h} . / \mathbf{y r}$ & Source \\
\hline ØRAS (NO), 2013 & 155 & 69,909 & 2.2 & Torneby, 2014 \\
Stockholm (SE), 2011 & 321 & 900,000 & 0.4 & Nystrøm, 2014 \\
Stockholm (SE), 2012 & 659 & 900,000 & 0.7 & Nystrøm, 2014 \\
Stockholm (SE), 2013 & 872 & 900,000 & 1.0 & Nystrøm, 2014 \\
SYSAV (SE), 2012 & $126^{4}$ & 157,500 & 0.8 & Eklund, 2014 \\
SYSAV (SE), 2013 & 97 & 157,500 & 0.6 & Eklund, 2014 \\
SYSAV (SE), 2014 & $100^{6}$ & 157,500 & 0.6 & Eklund, 2014 \\
Göteborg (SE), 2013 & 772 & 70,000 & 11 & Mårtensson, 2014 \\
Ballerup (DK), 2012 & 61 & 48,514 & 1.26 & Vestfor, 2014 \\
Sønderborg (DK), 2013 & 54 & 3,500 & 15 & Nielsen, 2014 \\
Ringsted (DK), 2012 & 205 & 30,000 & 6.8 & Dalgaard, 2014 \\
\hline
\end{tabular}

The table shows that the typical amount of hard bulky plastic waste collected at recycling centres lies between 0.5 and $15 \mathrm{~kg} /$ inhabitant (in the catchment area of the recycling centre)/year. The largest quantities are collected where large plastic items are accepted (garden furniture and other large items), the amounts may be overly large, since these items have only recently been introduced and stored items thus may have been gotten rid of, when the opportunity arose. The collected amount depend on the sorting guideline, information level, etc. However, an important parameter is also the amount of plastic delivered by businesses at the recycling centres, since the data has not been corrected for this factor. Thus, a large fraction of plastic from businesses could increase the collected amount per inhabitants substantially. Apart from that, there is no consistent relationship between the number of plastic fractions collected at the recycling centre and the amounts collected per inhabitant.

\subsubsection{Recyclability of the collected plastic}

The bulky waste plastic collected from recycling centres in the Nordic countries is typically a very mixed fraction containing many different plastic types as well as non-plastic. The table below shows the results of sorting analysis of plastic collected at recycling centres in Stockholm Municipality in 2011 and 2014. All analyses are performed by Swerec.

\footnotetext{
${ }^{4}$ Results for less than one year scaled up to 12 months.

${ }^{5}$ Assuming that the recycling centre covers half the population of Malmø Municipality (in total 2 recycling centres in Malmø).

${ }^{6}$ Results for less than one year scaled up to 12 months.

${ }^{7}$ Assuming that the recycling centre covers $1 / 8$ of the population of Sønderborg Municipality (in total 8 recycling centres).
} 
Table 6. Recyclability of the plastic collected at recycling centres in Stockholm (Swerec sorting analysis). Based on Nystrøm (2014) and Mårtensson, (2014)

\begin{tabular}{lrrrrrr}
\hline & $\begin{array}{r}\text { Hard } \\
\text { plastic }\end{array}$ & $\begin{array}{r}\text { Soft } \\
\text { plastic }\end{array}$ & $\begin{array}{c}\text { Other } \\
\text { plastic }\end{array}$ & $\begin{array}{r}\text { Non-rec } \\
\text { plastic }\end{array}$ & $\begin{array}{r}\text { Non- } \\
\text { plastic }\end{array}$ & $\begin{array}{r}\text { Recycle } \\
\text { rate }\end{array}$ \\
\hline Lövsta, 2011 & 45 & 14 & 20 & & 21 & 79 \\
Bromma, 2011 & 14 & 4 & 44 & & 39 & 61 \\
Stockholm, 2011 (Sept.) & 37 & 31 & & 10 & 22 & 68 \\
Stockholm, 2011 (Nov.) & 47 & 23 & & 7 & 23 & 70 \\
Stockholm, 2011 (Dec.) & 51 & 21 & & 6 & 22 & 72 \\
Östberga, 2014 & 58 & 4 & & 3 & 36 & 61 \\
Sätre, 2014 & 50 & 7 & & 0 & 43 & 57 \\
Lövsta, 2014 & 93 & 0 & & 7 & 0 & 93 \\
Bromma, 2014 & 53 & 12 & & 9 & 26 & 65 \\
\hline
\end{tabular}

The table shows that the part of the plastic collected at recycling centres actually being recycled typically lies in the range of $60-70 \%$.

\subsubsection{Synergy with other local systems}

When deciding on which fractions to collect, some of the recycling centres were taking other local systems into account.

In Norway and Sweden systems with a wide coverage have been put in place to handle packaging, including plastics, that are regulated by the packaging producer responsibility. Thus, plastic packaging is primarily collected through this system, which means that the recycling centres often do not collect these types of plastic waste and in other cases do supplementary collection of them also.

In Denmark, fractions collected at the recycling centres in some cases mimic the fractions collected through the household collection systems in order to make the fractions at the recycling centres more recognisable to the users. In some cases, sorting into more fractions is offered at the recycling centre than what is possible for the plastic collected directly at the households.

\subsubsection{Handling plastic containing hazardous substances}

A number of compounds, now registered as hazardous, have been used in the production of plastic products, typically either as plasticisers, colorants or biocides. In the last years, many of these compounds have been either phased out or restricted in use (primarily in plastics in contacts with food and in toys or other articles for children).

Since recycling of plastic materials containing hazardous substances is not favourable, if the intention is to restrict these substances in future plastic products, such plastic products should in principle not be recycled. This is quite difficult in practice. 
It should be taken into account, that more and more products are produced and imported from China. Many of these products are cheap, low quality or single use products. In China, there are no restrictions in the use of e.g. hazardous phthalates in food packaging or children's toys etc. These products can also end up at the recycling centres.

In general, the recycling centres have an overall awareness of the presence of hazardous substances in different types of especially older plastic products. Apart from in principle not accepting soft PVC for recycling, specific measures to minimise hazardous substances in the recycled plastic are not common. Suggestions for such measures were welcomed.

Klif (2013) is a listing and evaluation of hazardous substances in plastic. Based on this report an overview is given below of the compounds that are most likely to be found in the types of plastic products collected at recycling centres.

Especially soft PVC may contain phthalate-based plasticisers, e.g. BBP, DEHP, DBP, DiBP and DMEP. PVC used in products susceptible to microbial attack, e.g. shower curtains, may contain arsenic compounds. PVC may also contain Bisphenol A; the use in PVC manufacture is being phased out.

PVC from before 2001 and ABS products may contain cadmium (as a pigment or stabiliser). The same is true for lead chromates, which have been banned in some of the Nordic countries, but in EU only for plastics in contact with food. Cobalt di-acetate has been used for colouring especially PET bottles light blue. This is now being phased out.

Red and yellow plastic (especially old plastic or plastic produced outside the EU) may contain mercury or lead as part of the colour pigment.

Plastic from WEEE and end of life vehicles (ELV) often contain flame retardants and other additives. Furthermore, if WEEE is disposed with the electronics inside, this will contain metals (including heavy metals), batteries etc.

Polyaromatic hydrocarbons may be present in e.g. flip-flops and other plastic footwear, and in general in plastic materials coloured black, due to impurities in oil and coal based plasticisers.

A number of household products, e.g. toilet seats and food storage containers may contain triclosane as a biocide.

\subsubsection{Sorting experiment}

To investigate how large a share of the collected hard plastic that could potentially contain hazardous substances, an investigation of hard bulky waste plastic was performed at two recycling centers in Norway (ØRAS) 
and Sweden (Stockholm), respectively. In both cases, approximately one ton of plastic was sorted into different fractions: Plastic from WEEE, plastic from cars (end of life vehicles, ELV) as well as yellow and red plastic. These fractions were chosen based on a literature study on which plastic items that potentially could contain hazardous substances, see above.

Furthermore, the sorting quantified the fraction of black plastic, garden furniture and video cassettes. Finally, the rest of the plastic (not belonging to any of the above categories) and the non-plastic items were quantified.

The table below shows the results of the sorting.

The green color of the first lines in the table indicates that this plastic is suitable for recycling according to the current sorting guide and with very low risk of containing hazardous substances. However, black plastic may be discarded in the sorting, since NIR scanners are often not capable of recognizing black plastic.

Garden furniture is a homogeneous fraction with quite a lot of filling material (chalk), which lowers the general quality of the mixed plastic fraction. However, as a single fraction it may have an economic value.

The lines marked with yellow may be problematic for different reasons. Video cassettes contain long bands capable of wrapping around equipment in sorting plants etc., while yellow and red plastic (especially older plastic) may contain heavy metals due to the production of the pigment. Therefore, the red and yellow fraction of the plastic is not as such a problem, but there is a risk that part of this fraction contains hazardous substances. Plastic from ELV often contains different hazardous substances, e.g. flame-retardants.

The lines marked with red shows the plastic fractions that should not be there. PVC contains chloride and possibly flame-retardants, phthalates and other additives not suitable for recycling. For many plastic items it is difficult to define, whether it is made of PVC or other plastic types, e.g. PP or PE. Therefore, there is some uncertainty on the fraction of PVC in the sorting experiment. Plastic from WEEE often contains flame-retardants. Furthermore, if the actual electronic is still inside (which is often the case), the component also may contain metals (including heavy metals), batteries etc. The non-plastic items could be ceramics, textile, metal, etc. 
Table 7. Results of the sorting ecperiment at the two recycling centers, September 2014

\begin{tabular}{|c|c|c|c|c|}
\hline & Problematic issues & Comments & $\emptyset$ RAS & Stockholm \\
\hline Plastic, the rest & & & $39 \%$ & $58 \%$ \\
\hline Black plastic & Impurities. Difficulties in NIR sorting & & $18 \%$ & $10 \%$ \\
\hline Garden furniture & Plastic with chalk & & $15 \%$ & $13 \%$ \\
\hline Video cassettes (VHS) & $\begin{array}{l}\text { Problematic in sorting plants due to the } \\
\text { bands }\end{array}$ & & $8 \%$ & $0 \%$ \\
\hline Yellow and red plastic & Metals in the color pigment ( $\mathrm{Cd}$ and $\mathrm{Pb}$ ) & $\begin{array}{l}\text { Primarily in } \\
\text { older products }\end{array}$ & $5 \%$ & $13 \%$ \\
\hline Plastic from ELV & Flame retardants, other additives & & $1 \%$ & $1 \%$ \\
\hline PVC (hard/foil) & Flame retardants, phthalates & $\begin{array}{l}\text { Difficult to } \\
\text { recognize PVC }\end{array}$ & $5 \%$ & $3 \%$ \\
\hline WEEE & Flame retardants, metals etc. & & $3 \%$ & $0 \%$ \\
\hline Non-plastic items & & & $7 \%$ & $1 \%$ \\
\hline
\end{tabular}

For both recycling centers, the general plastic fraction was the largest (40-60\% of the total sorted amount), while the black plastic and garden furniture each constituted further $10-20 \%$ of the total. Since garden furniture constitutes a relatively large fraction of the collected material, it may be worth to consider collecting this fraction separately to improve the total value of the collected material.

The potentially problematic fraction of red and yellow plastic represented 5 and $13 \%$ respectively at the two sites. Although this is not a very large share of the collected plastic, a content of heavy metals in parts of this plastic may be problematic for the recycling. Therefore, it would be beneficial if the actual metal content in the collected plastic were investigated.

Video cassettes were only present in significant amounts in the ØRAS recycling center (8\%). To avoid problems with long bands in the sorting plants, it should be considered to omit these cassettes from the recyclable plastic.

The fraction of "red items" was relatively small, especially in Stockholm. There is some uncertainty about the PVC fraction, since it is very hard to determine whether a product is made from PVC or other plastic types. To minimize the share of PVC a sorting guide for plastics at the recycling center should specify products typically made of PVC.

The WEEE items found in the plastic fraction were typically toys, mobile phones and remote controls (all made of plastic, but with electronics inside). In the ØRAS recycling center, there were also a couple of larger 
items resulting in the share of 3\% WEEE of the total sorted amount. To eliminate WEEE in the plastic for recycling, the sorting guide at the recycling center should specify that WEEE, e.g. toys, mobile phones, remote controls etc., should not be disposed off via the plastic containers.

Based on the results of this initial sorting the following recommendations can be made:

- Include examples of typical PVC products in the sorting guide to avoid PVC in the plastic for recycling.

- Include examples of WEEE in the sorting guide to avoid WEEE in the plastic fraction.

- Maybe video cassettes should not be included in the plastic fraction.

- Separate collection of garden furniture may be economically preferable.

- Chemical analysis of the red and yellow plastic fractions ought to be carried out in order to investigate to what extent metals in the pigment is actually a problem for this fraction.

\subsubsection{Transport costs and administration of logistics}

The costs for transport and the resources needed for logistics is an important consideration to take into account when deciding which fractions to collect at the recycling centre.

Sorting of plastic into specific fractions can be influenced by the possibilities of minimising the transport cost. As an example, one of the interviewed municipalities was looking into sorting their recent mixed fraction into two fractions, hard- and soft plastic. The reason is that the municipality can trade the soft plastic locally and thereby minimise their overall transportation costs.

Another cost worth considering is related to the administration of the logistics and the trading of the different plastic fractions. Here one of the important messages from the recycling centres is to:

- remember to include the cost for handling of the actual logistics involved in the handling of the plastic

- include the administrative resources, which are needed for managing the actual trading of the plastic on the market. 


\section{Market opportunities}

This chapter describes the identified purchasers of plastic waste in the different Nordic countries, which fractions the different recycling centres have been able to sell, and the available information on obtained prices.

\subsection{Purchasers}

The interviews show quite clearly that the market for trade with plastic waste is under development. Some purchasers/users of "pure fractions" have primarily bought up plastic from industries, where the plastic is of one type of polymer without impurities. They are now gradually looking into the possibilities of also using plastic from recycling centres. Other major purchasers of plastic from recycling centres are the sorting facilities. This is due to the plastic from recycling centres being mixed or containing impurities in the form of other types of waste. It therefore needs to be sorted in order to obtain useable plastic fractions. This results in a market where most of the recyclable plastic from the recycling centres goes to sorting facilities. It may also go through an intermediary who handles the transport.

The purchasers found during the interview are listed in Table 1. The list represents all the purchasers found, and is therefore a mix of intermediaries, sorting facilities and plastic traders.

The number of purchasers working with plastic from recycling centres seems to be largest in Denmark (see Table 1), which is probably due to each municipality or waste management company in Denmark in general trading their own plastic. This is in contrast to Sweden and Norway, where respectively FTI and Grønt Punkt Norge trade the waste covered by the producer responsibility scheme. This combined with the fact that collection of plastic not included in the producer responsibility scheme is not as much in focus yet as in Denmark, may explain that there are not so many national purchasers.

Both the Faroe Islands and Iceland are dependent on purchasers abroad, since they do not have local sorting facilities. 
Table 1. Purchasers used by the interviewed municipalities and waste companies. Plastic sold abroad is marked by a nationality in parenthesis. The purchasers marked with bold are sorting facilities

\begin{tabular}{|c|c|c|c|c|c|}
\hline Denmark & $\begin{array}{l}\text { Faroe } \\
\text { Islands }\end{array}$ & Finland & Iceland & Norway & Sweden \\
\hline Danbørs & $\mathrm{ES} \varnothing(\mathrm{DK})$ & Muovix oy ${ }^{8}$ & $\begin{array}{l}\text { IL Recycling } \\
\text { (S) }\end{array}$ & $\begin{array}{l}\text { Grønt punkt } \\
\text { Norge }\end{array}$ & Dela (D) \\
\hline DK Raastoffer $\mathrm{A} / \mathrm{S}^{9}$ & Stena (DK) & & & Alba (D) & FTI \\
\hline Expladan & & & & Dela (D) & Swerec \\
\hline Marius Pedersen & & & & $\begin{array}{l}\text { Norsk } \\
\text { gjenvinning }\end{array}$ & \\
\hline Ragn-Sells & & & & Swerec (S) & \\
\hline $\mathrm{RC}$ plast & & & & & \\
\hline Returplast $\mathrm{A} / \mathrm{S}$ & & & & & \\
\hline RGS90 & & & & & \\
\hline Stena & & & & & \\
\hline WUPPI (specialized in PVC) & & & & & \\
\hline Aage Vestergård Larsen APS & & & & & \\
\hline
\end{tabular}

\subsection{Fractions currently sorted at recycling centres}

According to the purchasers, all plastic fractions can be accommodated, but to give information on the realistic market at present, an overview is given of the actual fraction that the recycling centres collect and sell today. Table 2 is therefore not a complete list, but examples of what is done and thus possible today. Other fractions may be more relevant in specific situations.

${ }^{8}$ At the time of the interviews, the collection of plastic in Finland was in an initial stage including the collaboration with Muovix oy.

${ }_{9}^{9}$ Plant is no longer in operation. 
Table 2. Overview of collected fractions in the Nordic countries. Greenland is not included since recycling of plastic is not considered possible under the current conditions ${ }^{10}$

\begin{tabular}{|c|c|c|c|c|c|c|}
\hline Fraction & Denmark & $\begin{array}{c}\text { Faroe } \\
\text { Islands }\end{array}$ & Finland & Iceland & Norway & Sweden \\
\hline Big bags (white nylon) & & $x$ & & & & \\
\hline Bottles (PET) clear & $x$ & & & & & \\
\hline Bottles (PET) coloured & $x$ & & & & & \\
\hline Car bumpers & $\mathrm{x}$ & & & & & \\
\hline Containers (mix - clean and without hazardous symbols) & $x$ & & & & $x$ & \\
\hline Buckets etc. (only PE) & $x$ & & & & & \\
\hline Buckets etc. (only PET) & $\mathrm{x}$ & & & & & \\
\hline Tin crates for milk or bread & $x$ & & & & & \\
\hline DVDs and CDs & $\mathrm{x}$ & & & & & \\
\hline EPS & $x$ & & & & $\mathrm{x}$ & \\
\hline Foil - clear & $x$ & $x$ & & & & \\
\hline Foil - coloured & $x$ & $x$ & & & & \\
\hline Foil - mixed both clear and coloured. & $x$ & & $x$ & & $\mathrm{x}$ & \\
\hline Food waste - plastic (covered bythe recycling fund) & & & & $\mathrm{x}$ & & \\
\hline Garden furniture (plastic) & $x$ & & $x$ & $(x)$ & $x$ & \\
\hline Hard plastic (buckets, boxes, toys) incl. PVC & $\mathrm{x}$ & & & & $x$ & $\mathrm{x}$ \\
\hline Hard plastic (buckets, boxes, toys) w/o PVC & $x$ & & $x$ & & & \\
\hline Hard plastic from packaging & & & $x$ & & & \\
\hline Large hard plastic from industries & & & & $x$ & & \\
\hline Mixed plastic fraction, all plastic incl. PVC - & & & & & & $x$ \\
\hline Nets (nets, trawls) & & $\mathrm{x}$ & & & & \\
\hline Plastic packaging (producer responsibility materials) & & & & & $x$ & $x$ \\
\hline PVC (Hard) & $x$ & & & & & \\
\hline VHS, cassette tape, floppy disc & $x$ & & & & & \\
\hline
\end{tabular}

From Table 2, it is clear that there is a big difference between the different countrie's collection of plastic. Greenland and Faroe Islands do not collect plastic for recycling at recycling centres at all. The reason for this can be that both these countries have the challenges of great distances both regarding collection nationally and then again internationally to a possible purchaser.

In Finland, the plastic collection is in a transition phase, going from no collection of plastics from households to collection of packaging materials from households due to a change in their producer responsibility scheme. The producer responsibility scheme currently only covers industrial packaging, but will now also include packaging materials from households. Due to this transition, any ongoing collection of packaging plastic from households at recycling centres is at the moment at a pilot scale.

\footnotetext{
10 Greenland has the challenge that there are large distances between the communities and to a possible purchaser. Therefore it is assessed by KANUKOKA that collection of plastic is n either possible nor beneficial economically or environmentally.

11 Faroe Islands only collects recyclable plastic from industries, not from households
} 
The reduced focus on plastic collection at recycling centres in Sweden and Norway is to some extent a positive effect of the producer responsibility scheme run by FTI (Förpacknings- och tidningsinsamlingen) and Grønt Punkt Norge. If there is any separate collection of plastics at a recycling centre, this is often one fraction based on the packaging plastic included in the producer responsibility scheme (see example in 0 ), and one mixed plastic fraction for the rest of the plastic, hard as well as soft, as can be seen in Table 2. Some places, the collection of packaging plastic is carried out through kerbside collection or similar, and therefore collection of plastic at the recycling centre has not been a priority. This seems to be changing in Sweden towards collection of the plastic not included in the producer responsibility scheme at the recycling centres.

There is one challenge for the recycling centres with producer responsibility system: The two waste streams, packaging- and non-packaging plastic, cannot be mixed, due to the organisation of the further handling.

Denmark has not created a producer responsibility system with a wide coverage, so traditionally all collection of recyclable plastic from households and small businesses is carried out at the recycling centres. ${ }^{12}$ In Denmark, the collection of plastic includes a number of potential fractions, which often differ from recycling centre to recycling centre dependent on the local conditions and purchaser agreements. The driver for the separation into more fractions is the possible higher prices for more pure fractions and the aim of achieving a higher degree of overall recycling of plastics. Some recycling centres focus on separating out the valuable plastic fractions, while other recycling centres prefer less fractions, due to e.g. space limitations, transport distance to purchasers, user friendliness etc. (see for example 0).

\subsection{Prices}

The sorting of plastic is often a political decision to increase recycling rather than an economic decision. However, once the decision is made to sort plastic, the plastic can be sorted in different fractions, and here the economic perspective can become an important factor.

12 Apart from the system for certain types of beverages. 
The following paragraphs compile the collected information on prices for the different fractions and the importance of transportation costs and resource demand for managing logistics and trades.

\subsubsection{Price trends}

An overview of the gathered prices is listed in Table 3. The general trend is that the purer the fraction, the higher the price. Besides the purity, some types of plastic at the moment represent a higher value, especially foils, followed by bottles and buckets sorted by specific polymers. Other more specific fractions, like car bumpers and garden furniture, represent a value, if they are sorted out. The plastic with the lowest economic value was plastic containing PVC. Here the hard fraction can be recycled, whereas the soft PVC is going to landfill or incineration dependent on national legislation and practise. One has to be aware that transport costs have to be added, and they can be significantly higher than the prices obtained for the plastic.

Table 3. Overview of collected prices. Positive figures indicate that plastic has a positive value, and negative figures indicate that a price has to be paid to dispose of the plastic

\begin{tabular}{lrr}
\hline Fraction & $\begin{array}{r}\text { Range } \\
\text { low [EUR/ton] }\end{array}$ & $\begin{array}{r}\text { Range } \\
\text { high [EUR/ton] }\end{array}$ \\
\hline Big bags (white nylon) & 40 & 40 \\
Buckets etc.(mix - clean and without hazardous symbols) & -60 & 420 \\
Buckets etc. (only PE) & 110 & 110 \\
Buckets etc. (only PET) & 110 & 110 \\
Car bumper & 30 & 30 \\
Crates for mill or bread & 260 & 260 \\
Foil - clear & 270 & 370 \\
Foil - coloured & 30 & 190 \\
Foil - mixed both clear and coloured. & 70 & 100 \\
Garden furniture (plastic) & 30 & 40 \\
Hard plastic (buckets, boxes, toys) incl. PVC & -20 \\
Hard plastic (buckets, boxes, toys) w/o PVC & -20 & 0 \\
Mixed plastic fraction, all plastic incl. PVC & -10 & 150 \\
Plastic packaging (producer responsibility materials) & -170 & 13 \\
PVC (Hard) & 150 & 90 \\
\hline
\end{tabular}

13 Price set by Grønt Punkt Norge. 



\section{Quality and recyclability}

When trading the plastic, the purchasers will require that the plastic fraction has a maximum content of impurities. The recycling centres will on the other hand require information of the actual degree to which the plastic is recycled and what it in principle is used for (what is the level of down cycling if any).

In this chapter, an overview of the purity demands encountered will be given, and likewise the current knowledge about the recyclability of the different fractions.

\subsection{Purity}

The purchasers often set a requirement for the maximum allowed impurities for each plastic fraction. These requirements are presented in Table 4 . The requirements vary from purchaser to purchaser.

\begin{tabular}{|c|c|}
\hline Fraction & Allowed impurity [\%weight foreign plastic allowed] \\
\hline $\begin{array}{l}\text { Buckets. etc. (mix - clean and without } \\
\text { hazardous symbols) }\end{array}$ & $90 \%$ hard plastic and of this, a minimum $60 \% \mathrm{PE}$ or PP \\
\hline Buckets etc. (only PE) & no soil \\
\hline Crates for milk and bread & There are no impurities \\
\hline Foil - clear & $2 \%$ \\
\hline Foil - coloured & $0 \%$ \\
\hline Foil - mixed both clear and coloured. & Has to be clean, if there is soil in it, it will all be discarded \\
\hline Garden furniture (plastic) & $3 \%$, no soil \\
\hline Hard plastic (buckets, boxes, toys) w/o PVC & $2-3 \%$ \\
\hline $\begin{array}{l}\text { Plastic packaging (producer responsibility } \\
\text { materials) }\end{array}$ & $\begin{array}{l}5 \% \text { impurity (from tree or paper) } \\
5-10 \% \text {, improvements required } \\
10->\text { (they stop the delivery or send a bill) }\end{array}$ \\
\hline PVC (Hard) & $\begin{array}{l}\text { The purchaser has no problem with impurity. The problem is } \\
\text { at the recycling centre, because people put other plastic types } \\
\text { than PVC in the container. This gives a higher total, since the } \\
\text { price for disposal of PVC is high. }\end{array}$ \\
\hline
\end{tabular}


One thing is the actual requirements from the purchasers, another thing is, how the requirements are met. The municipalities, waste companies and the purchasers are all interested in better communication to ensure that the correct purities are reached.

The identified need for communication regarding impurities between the municipalities and waste management companies on one side and the purchasers on the other side is further described in the guideline and some recommendations are given on how to ensure increased communication in Chapter 7 of this report.

\subsection{Recyclability of the plastic could be more transparent}

The information on the actual flow of the plastic after it has left the recycling centre is not as transparent as many of the recycling centres would like. It is only some sorting facilities that can give a percentage of how much of the plastic that is sorted out and sold as recycled plastics. It is important for the municipalities and waste companies to know how big a fraction that can actually be recycled in order to meet the legal requirements set. There is thus another communication issue here.

There is also lack of information with respect to what actually happens next in the value chain with the recyclable plastic, e.g. whether the plastic is upcycled or down cycled is often not a part of the communication between the purchaser and the municipality or waste management company.

These issues have led to recommendations on how to improve the communication between the municipalities and waste management companies and the purchasers. The recommendations are presented in Chapter 7 of this report. 


\section{Information of the personnel and the users}

During the interviews, it has been established that a key factor to success is the information to the users as well as to the personal. The identified issues on communication are presented in the following paragraphs.

\subsection{Personnel as communicators}

It is clear from the interviews that the personnel play a major role in securing the quantity and quality of the plastic fractions. It is important that the personnel is knowledgeable with respect to which types of plastic goes where and why, that is how are the different fractions handled further downstream, what are the potential products that can come out of it, and what can go wrong in this process, if material is by mistake put in the wrong place. According to the interviews, knowledge about these questions can motivate the users as well as the personnel. How personnel can act as communicators is further elaborated in the guideline.

\subsection{Information at the recycling centre}

The information at the recycling centre should be easily understandable and containers should be marked clearly with lists of typical products and e.g. pictures of these.

It is also important to inform users on which types of plastics that are not desired in the containers for plastic and the acceptable degree of contamination purity e.g. food leftovers or detergents in the plastic packaging.

Suggestions to how this can be achieved are given in the guideline and in 0 . 


\subsection{Online information}

The recycling centres all use online media to present information to the users. The information can inform the user about location of recycling centres, on which different plastic types that should be sorted separately and the location of each container at the recycling centres.

Based on the interviews and a search on the recycling centres homepages, experiences on online information are presented in the guideline.

\subsection{Training of personnel}

Based on the interviews, it is established that it is of high importance that the personnel at the recycling centres are both willing to help and motivated for recycling. Therefore it is important that the personnel is trained and educated in correct sorting and in waste recycling processes (in general and especially with respect to the processes relevant for the recycling centre in question) so that the staff can encourage the users of the benefit of recycling both with respect to costs, use of resources and environmental impacts.

What the training of the staff can include is presented in the guideline and some examples are given in 0 . 


\section{Recommendations}

A number of more general issues and recommendations were raised by the interviewees, which will be summarised in this chapter.

\subsection{Information and dialogue with purchasers}

A general issue that should be emphasised is the need for continuous communication between purchasers and the suppliers of the plastic waste. This is true for the direct communication between a recycling cycling centre and the sorting plant and recyclers receiving their plastic waste, but also in general.

Plastic waste covered by extended producer responsibility (EPR) is usually handled through larger agreements by the national collective collection schemes. Operators of recycling centres usually do not experience many problems in delivering this waste, and the national collection scheme usually undertakes the delivery and final treatment of the waste. However, plastic waste not covered by EPR is often either not collected separately or managed by each municipality or waste management company separately.

The managers of the recycling centres express that they find it difficult to find general and specific information from the purchasers on the specific requirements related to the different types of plastic waste, comingled or separately collected. They also find it difficult to get an overview of which plastic fractions can actually be sold. This report lists fractions typical at present, but this will change over time, and an instrument to produce a more continuous overview could greatly enhance the initiatives on further collection of plastic waste. The recyclers also welcome increased dialogue and flow of information in order to prevent erroneous sorting and the subsequent "contamination" of specific plastic streams: 
- A price structure of different materials and qualities insuring transparency of how quality and costs are related

- An overall list of purchasers and the fractions and qualities they accept, making it easier to find an appropriate sorting/recycling facility. This could for instance be established and maintained by the industrial organisation of sorting and remanufacturing facilities.

\subsection{Dialog between recycling centres}

Availability of experiences from the operators of the recycling centres already handling more fractions of plastic waste could benefit the sector, and already today, many experiences are shared between the operators, but on a coincidental basis. Common forums or platforms for the exchange of good and bad experiences could increase the sharing of knowledge. These forums or platforms could be initiated and maintained within the national waste federations (Avfall Norge, Avfall Sverige, Dakofa and similar).

\subsection{Dissemination and further work}

It has been stated by many recycling centres that the relevant stakeholders will not read a guideline in English, and it is therefor a wish that the guideline is translated into the Nordic languages.

Since a common forum for the exchange of information between recycling centres and between recycling centres and purchasers is much sought after by the stakeholders, it would be greatly appreciated if the Nordic Wast group could initiate the establishment of such a forum.

Content of hazardous substances in some plastic fractions may be go against the overall aim of recycling and thus reduced as much as possible. At present, there is knowledge on the plastic fractions that could contain hazardous substances, but not on the concantratons of these substances typically found in a mix of the relevant plastic items. Further studies on this issue will greatly help the decisions on, how stringent one should be in trying to avoid these fractions. 


\section{Literature}

AffaldPlus. (16th October 2013). (A. Weidling, Interviewer).

Agderrenovasjon. (2013). SORTERINGSGUIDE. Online brochure:

http://agderrenovasjon.no/husholdning/wp-

content/uploads/2013/08/Engelsk_norsk_A4_sorteringsuide_trykkorg.pdf

Bøjskov, J. (31st October 2013). Sønderborg Forsyning. (A. Weidling, Interviewer).

Cuculiza, F. (2013). Genanvendelse af plast- hvor langt er vi? - Succes med plastik til genbrug. Presentation from DAKOFA konference, Aage Vestergaard Larsen ApS.

Dalgaard Nielsen, J. (09th October 2014). Affaldplus. (A. wejdling, Interviewer).

Dubrovskis, M. (2012). Action 1.2 Report on waste plastic in Liepaja Waste

Management Region. Plastic ZERO - Public Private Cooperation for Avoiding Plastic as a Waste.

Eklund, C. (19th September 2014). SYSAV. (T. L. Neidel, Interviewer).

Fischer, C. (2013). Municipal waste management in Iceland. EEA.

Fråne, A., Stenmarck, Å., Sörme, L., Carlsson, A., \& Jensen, C. (u.d.). Kartläggning av plastavfallsströmmar i Sverige. SMED.

FTI. (2013). Även en tom plastförpackning är full av framtidsutsikter. Brochure.

FTI. (2013). Återvinn dina plastförpackningar. Online brochure: http://plast.ftiab.se/ sorteringsguide.aspx

Hansen, E., Nilsson, N. H., Lithner, D., \& Lassen, C. (2013). Hazardous substances in plastic materials. COWI.

Hohberg, J. (2013). Fredericia plastsortering og genanvendelse Hvad kan vi?, hvor har vi udfordringer? Presentation from DAKOFA konference, DKRaastoffer.

Mårtensson, P. (31st October 2013). Department of Sustainable Waste and Water, City of Gothenburg. (A. Weidling, Interviewer).

Mårtensson, p. (2014, 10 13). Department of Sustainable Waste and Water, City of Gothenburg. (A. Wejdling, Interviewer).

NAG. (2013). Resource efficient recycling of plastic and textile waste-Preliminary report prepared for the Nordic Council of Ministers Project number: 2012.05.21, Date 7th February 2013.

Neidel, T. L. (2011). Amagerforbrænding - Erfaringer omkring indsamling af plast. Notat, COWI.

Nielsen, L. (9th October 2014). Sønderborg Forsyning, Skodsbøl. (A. Wejdling, Interviewer).

Nystrøm, P. (May 2014). Recycling of municipal plastic waste - The approach of Stockholm City.

Petersen, C. (2013). Ressourceeffektiv genanvendelse af plastaffald Plastaffald i tal og en rapport fra Nordisk Ministerråd. Presentation from DAKOFA konference, Econet AS.

Pettersson, J. (2012). Færch Plast utvecklar detekterbar svart PET. Online article, http://m.packnyheter.se/default.asp?id=6523\&show=more

REMIKS. (2012). Plukkanalyse remiks miljøpark - September-oktober 2012. 
Routa-Lindroos, S. (2012). Action 1.2 Report on waste plastic in Tampere Region. Plastic ZERO - Public Private Cooperation for Avoiding Plastic as a Waste.

Stockholm. (2012). Dina sopor - en resurs i Norra Djurgårdsstaden. Folder, Municipality of Stockholm.

Stockholm. (2013). Avfallsplan för Stockholm 2013-2016 - på väg mot ett Stockholm i världsklass. Municipality of Stockholm.

Stockholm. (2013). Bilagor till Avfallsplan för stockholm 2013-2016. Avfallsplan, Municipality of Stockholm.

SYSAV. (2013). Sorting guide. Online brochure: http://www.sysav.se/Templates/ printao.aspx?PageLink=272

Sønderborg_Affald_A/S. (2011). Miljøredegørelse 2007-2011.

Sønderborg_Forsyning. (2013). Forsyningshåndbog Sønderborg Forsyning. Brochure, Sønderborg Forsyning.

Torneby, P. (19th September 2014). ØRAS. (T. L. Neidel, Interviewer).

Vestforbrænding. (18, 09. October, october 2013, 2014). (A. Weidling, Interviewer).

ØRAS. (2012). Slik sorterer du på gjenvinningsstasjonen. Online brochure: http://www.oeras.no/paa-gjenvinningsstasjonen/slik-sorterer-du-paagjenvinningsstasj

ØRAS. (2013). Oversiktskart. website: http://www.oeras.no/kart-over-gjenvstasjonen/category217.html 


\section{Resume (in Danish)}

Nærværende rapport er en baggrundsrapport til "Guideline of plastic sorting at recycling centres". Formålet med guidelinen er at hjælpe genbrugsstationerne med den beslutningsproces, de skal i gennem, hvis de ønsker at indsamle mere plastik på genbrugsstationerne i en bedre kvalitet. Den overordnede ambition er at sikre udsortering af det meste af den genanvendelige plast. Guidelinen henvender sig til både store og små genbrugsstationer.

Baggrundsrapporten beskriver den metode, der er anvendt ved udarbejdelsen af guidelinen, hvilket omfatter indsamling af erfaring og holdninger vedrørende indsamling af plastik på genbrugsstationer. Dette er sket via interviews med genbrugsstationer / kommuner / affaldsselskaber, indkøbere og oparbejdere af plastikaffald. Interviewene er blevet suppleret med indsamling af relevant litteratur og internetinformationer samt en diskussion af resultaterne på workshops med parterne i henholdsvis november 2013 og oktober 2014.

I baggrundsrapporten præsenteres først information fra eksisterende systemer og de forskellige parter, som genbrugsstationerne kan bruge direkte i beslutningsprocessen: Hvordan de forskellige typer af plastik kan indsamles og håndteres på genbrugsstationen, hvordan indsamlingen på genbrugsstationen bør indtænkes i det samlede indsamlingssystem, og hvordan plastic med indhold af farlige stoffer kan undgås i det genanvendte plastik (kapitel 3).

Dernæst beskrives vigtigheden af, at der sikres en god kommunikation imellem genbrugspladserne og opkøberne. Kommunikationen går bl.a. på at afstemme forventningerne om renheden af plasten fra genbrugspladsen, og sporbarheden af plasten fra det er leveret til opkøberen og videre ud i værdikæden (kapitel 4 og 5).

Efterfølgende beskrives vigtigheden af, at der er en god information til både personale og brugere (kapitel 6). Til slut er oplistet nogle anbefalinger vedrørende mere vidensdeling blandt genbrugspladser og indkøbere, et ønske der er blevet fremhævet igennem flere af interviewene (kapitel 7).

Appendix A til D indeholder information om den til projektet knyttede referencegruppe, de spørgsmål der er stillet i forbindelse med indsamlingen af information fra diverse organisationer, eksempler på "Best Practice" og til slut en oversight over litteratur og andre kilder, der har været brugt som baggrundsinformation for projektet. 
Rapporten er en del af de nordiske statsministres grøn vækst initiativ "Norden - førende inden for grøn vækst". Læs mere i webmagasinet "Green Growth the Nordic Way" på www.nordicway.org eller www.norden.org/greengrowth 


\section{Appendix A: Reference group}

\begin{tabular}{|c|c|c|c|}
\hline Country & Institution & Role & Contact person \\
\hline Denmark & I/S Vestforbrænding & Public Waste Company & Mette Kyed \\
\hline Denmark & Københavns Kommune & Public Sector & Mette Skovgaard \\
\hline Denmark & Sønderborg Forsyning & Public Waste Company & Jette Bøjskov \\
\hline Denmark & Vejle Kommune & Municipality & Karen Lübben \\
\hline Finland & Pirkanmaan Jätehuolto Oy & Waste recycling & Simon Isoaho \\
\hline Norway & Remiks & Public Waste Company & Ivar Sture Handeland \\
\hline Norway & $\varnothing \mathrm{RAS}$ & Public Waste Company & Pål Torneby \\
\hline Sweden & $\begin{array}{l}\text { Förpacknings- och tidningsin- } \\
\text { samlingen (FTI) }\end{array}$ & Waste recycling & Tord Görling \\
\hline Sweden & Borealis & Raw material producer & Thomas Hjertberg \\
\hline Sweden & INEOS Chlor Vinyls & Plastic Producer & Lars Josefsson \\
\hline Sweden & $\begin{array}{l}\text { Kretslopp och vatten, Göteborg } \\
\text { kommune }\end{array}$ & Public Sector & Pål Mårtensson \\
\hline Sweden & Stockholm & Municipality & Peter Nyström \\
\hline Sweden & SYSAV AB & Public Waste Company & Carina Eklund \\
\hline
\end{tabular}





\section{Appendix B: Questionnaire}

\section{A. Questions for operators of recycling centers (municipalities, public utility companies, private operators)}

The questions can be answered for a single recycling center or an area, depending on the data available.

1) Name of the recycling center/area covered.

2) How many inhabitants does the recycling center/area cover?

3) Are there additional collection systems for plastic waste in the area (e.g. curb side collection or bring banks)? Please explain the system (short).

4) Describe the set-up for collection of plastic at the recycling center (receptacles, compactors, area requirements, collection frequency etc.). Which plastic types are collected (separate/mixed)? Examples could be rigid plastic, foil, bottles, PVC, garden furniture etc.

5) How much plastic is collected (ton/year)?

And how is the polymer distribution (of known)?

Please insert the plastic collected fractions specified in " 4 " in the table below.

\begin{tabular}{|l|l|l|l|}
\hline $\begin{array}{l}\text { Collected fraction } \\
\text { (see question 4) }\end{array}$ & $\begin{array}{l}\text { Amount collected } \\
\text { t/year }\end{array}$ & Primary polymer(s) & $\begin{array}{l}\text { Amount collected through other } \\
\text { collection schemes if available } \\
\text { t/year }\end{array}$ \\
\hline & & & \\
\hline & & & \\
\hline & & & \\
\hline & & & \\
\hline & & & \\
\hline & & & \\
\hline
\end{tabular}

6) Are there any types of plastics you do not or preferably do not receive at the recycling centre?

e.g.:

○ ABS, EPS, PVC, film, agricultural films, etc.

- Plastic bottles marked with European hazard symbols.

○ Other??? 
7) Who is purchasing the collected plastic and what is the further treatment and application (as specific as possible, e.g. "recycling as garden furniture")?

\begin{tabular}{|l|l|l|}
\hline $\begin{array}{l}\text { Collected fraction } \\
\text { (see question 4) }\end{array}$ & Purchaser & Further application \\
\hline & & \\
\hline & & \\
\hline & & \\
\hline & & \\
\hline & & \\
\hline & & \\
\hline
\end{tabular}

8) What is the quality of the collected material with respect to purity ( $\%$ of the targeted plastic) and price?

\begin{tabular}{|l|l|l|}
\hline $\begin{array}{l}\text { Collected fraction } \\
\text { (see question 4) }\end{array}$ & $\begin{array}{l}\text { Purity } \\
\text { \% plastic (weight) }\end{array}$ & $\begin{array}{l}\text { Price } \\
\text { EUR/ton }\end{array}$ \\
\hline & & \\
\hline & & \\
\hline & & \\
\hline & & \\
\hline & & \\
\hline & & \\
\hline
\end{tabular}

9) Information: Describe how the collection system for plastic is communicated to the customers and the recycling center personnel?

10) What are the main practical experiences from the collection systems?

○ Understandability of the system:

- Incorrect sorting (main problems):

○ Other typical problems:

11) What are the costs of collection of the different plastic fractions (costs - income from materials, kr./ton collected plastic)?

12) What suggestions do you have for improvements in your own system?

13) What would you suggest to be the major issues to address in a guideline, if more plastic is to be collected at the recycling stations?

14) What would you suggest to be the major issues to address in a guideline, if better quality of the plastic fractions is to be collected at the recycling stations? 


\section{B. Questions for purchasers of the plastic fractions}

1) Name of the company.

2) Do you have experience with plastic waste collected from recycling centers?

3) What are the typical plastic fractions you receive from recycling centers (e.g. rigid plastic, foil, bottles, PVC, garden furniture)?

4) For each of the plastic fractions in " 13 ", what is the purity (\% of targeted plastic), polymer distribution and your price (typically)?

\begin{tabular}{|l|l|l|l|}
\hline $\begin{array}{l}\text { Collected fraction } \\
\text { (see question 13) }\end{array}$ & $\begin{array}{l}\text { Purity } \\
\text { \% target plastic }\end{array}$ & Primary polymer(s) & $\begin{array}{l}\text { Price } \\
\text { EUR/ton }\end{array}$ \\
\hline & & & \\
\hline & & & \\
\hline & & & \\
\hline & & & \\
\hline & & & \\
\hline & & & \\
\hline
\end{tabular}

5) Are there any types of plastics you do not or preferably do not receive/purchase?

e.g.:

$\bigcirc$ ABS, EPS, PVC, film, agricultural films, etc.

○ Plastic bottles marked with European hazard symbols

○ Other???

6) Suggestions for improvement of typical collection set-ups at recycling centers? 



\section{Appendix C: Best Practice examples}

In this appendix, three examples of best practices are presented. They are chosen in order to show the variety of solutions that can fit different settings. Several examples are shown, since there is not one solution that will be best for all.

The best practice examples are taken from:

- Göteborg: an example of focus on user friendliness, and less source separation.

- Sønderborg: focus on high quality fractions based on collection of many fractions and the use of a municipal sorting facility. Sønderborg is also an example of a smaller community in a more rural area.

- Vestforbrænding: an example of a solution somewhere between Sønderborg and Göteborg. The example given is from one of the municipalities that are part of Vestforbrænding.

For each example, a short introduction is given to the other plastic collection systems in the area, to give an idea about the overall setting. Then a list of collected fractions is presented, and last examples of how the users and personnel are informed.

\section{Göteborg - Kretsloppsparken Alelyckan, Sweden}

The overall setup of plastic collection consists of five recycling centres in Göteborg and approx. 340 kerbside containers for materials included in the producer responsibility on packaging (FTI) in Göteborg.

The overall plastic waste streams are mainly based on the two streams: plastic included in the producer responsibility scheme, and plastic not included in the producer responsibility scheme.

The municipality of Göteborg has been chosen as a case, because they have designed a system, where the user meets the same fractions in the kerbside collection and at the recycling centre. Additionally, Göteborg 
has chosen to make the plastic collection at the recycling centre as easy for the user as possible, by setting up one container for almost all plastic types, incl. plastic in the producer responsibility scheme (see Figure 1).

\section{Fractions collected, containers and why these fractions are selected}

The data presented in Table 5 is based on one of the recycling centres, Kretsloppsparken Alelyckan, in Göteborg. As can be seen from the table, two fractions are collected: one only for the plastic included in the producer responsibility on packaging and one for (almost) all types of plastic. The container that is only for packaging plastic is placed outside the fence of the recycling centre, and is available 24 hours. The container for all plastic types is placed inside the recycling centre, and is available during the recycling centres opening hours.

The reason for this very simple system is to make the collection as user friendly as possible. The plastic with hazardous symbols is handled as hazardous waste, and is therefore not a part of the recyclables.

\begin{tabular}{|c|c|c|c|c|c|}
\hline Fractions & Container & $\begin{array}{r}\text { Amounts } \\
\text { [Ton/year] }\end{array}$ & $\begin{array}{l}\text { No. of visitors } \\
\text { [pers./year] }\end{array}$ & $\begin{array}{r}\text { Amounts per } \\
\text { visitor } \\
{[\mathrm{kg} / \mathrm{visitor}]}\end{array}$ & Reason \\
\hline Packaging plastic & $\begin{array}{l}\text { Containers } \\
\text { provided } \\
\text { by FTI }\end{array}$ & 7.85 & $\begin{array}{l}\text { Open } 24 \\
\text { hours daily, } \\
\text { not manned. }\end{array}$ & - & Set by FTI \\
\hline $\begin{array}{l}\text { All plastic types incl. } \\
\text { PVC and EPS. (Except } \\
\text { for plastic with hazard- } \\
\text { ous symbols) }\end{array}$ & $\begin{array}{l}32 \text { cubic } \\
\text { container }\end{array}$ & 772 & 35,350 & 22 & $\begin{array}{l}\text { All plastic is } \\
\text { collected togeth- } \\
\text { er incl. packaging } \\
\text { plastic, to make it } \\
\text { easier for the } \\
\text { users }\end{array}$ \\
\hline
\end{tabular}

\section{Information for users and personnel}

The main issue communicated is why plastic should be collected separately.

\section{User information at the recycling centre}

- Personnel are present at the containers at all times, so users can ask questions. Further, the personnel are proactive and try to be available for the users, instead of the users having to find the personnel. In Göteborg, contact between personnel and users is seen as very important for the user friendliness and the quality of the collected fractions. 
Figure 1. Signs used at the recycling centres. Right) sign used at Kretsloppsparken Alelyckan. Left) official sign used for the mixed fraction of plastic

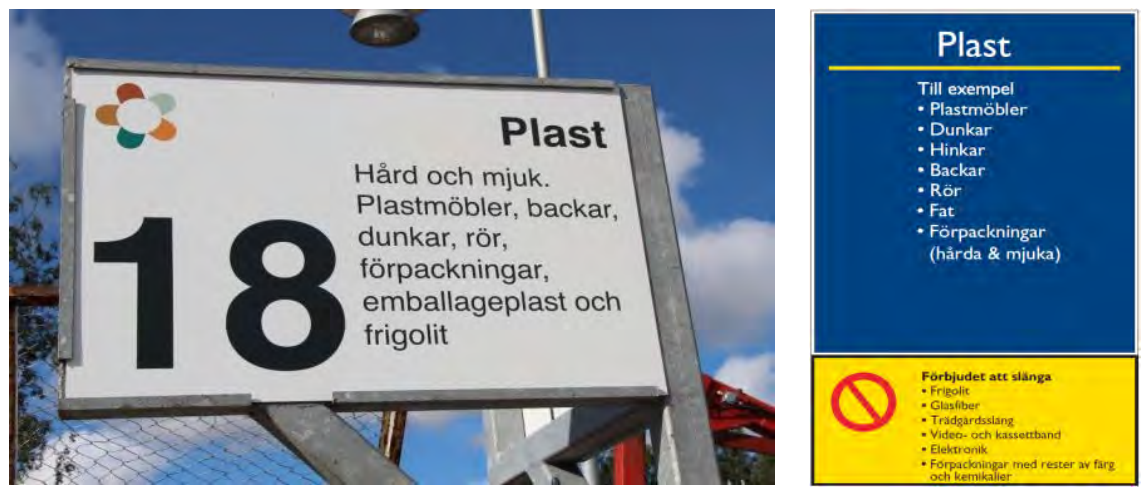

- To guide the users at the recycling centre, there are signs with text telling what can go where (see Figure 1, right).

- The placement of the different containers has an effect on the user's ability to sort correctly. Having the container with combustibles near the plastic container has helped users not to put fractions in the plastic container that should have gone to the combustible fraction.

\section{User information outside the recycling centre}

- Information for the users outside the recycling centre is based on brochures and the Internet (the municipality homepage).

\section{Information for personnel}

- Previously, the personnel were sent to SWEREC to learn about plastic sorting etc. Today, Göteborg has made their own educational program.

\section{Sønderborg Forsyning - Skodsbøl genbrugsstation, Denmark}

The plastic collection in the municipality of Sønderborg consists of recycling centres and household collection of dry fractions incl. foils and tubs, buckets, etc. In 2012, the household collection resulted in 108 tons of buckets and 72 tons of foil. These figures cover the whole area of Sønderborg, where Skodsbøl recycling centre is one out of eight recycling centres.

The municipality of Sønderborg runs a sorting facility, where they carry out manual sorting of the larger plastic items, shredding and packing of plastic. The recycling centres are customers at the sorting facility. 
The municipality of Sønderborg has been chosen as a case, because the municipality has chosen to separate the plastic into many fractions at the recycling centre, and due to their municipal sorting facility.

\section{Fractions collected, containers and why these fractions are selected}

The data presented in Table 6 is based on one of the eight recycling centres in Sønderborg. From the table it can be seen that the waste is separated into many plastic fractions based on product type, polymers, and whether the plastic is hard or soft. The different fractions are chosen based on the market prices being higher, if some fractions are sorted out separately.

In order to lower the transport costs, the foil is pressed at the recycling centre. The pressing is done with a compactor, which was originally used for cardboard. There is a compactor at each recycling centre. Once the foil is compacted, it is sold.

EPS goes in to the combustible fraction at this recycling centre. Sønderborg Forsyning has tested if it was possible to collect EPS at all their recycling centres, but the transport costs were too high. In order to make the transport economically feasible, an EPS compacter at each recycling centre is needed, but a compacter for EPS is very expensive. There is one recycling centre in the area which takes EPS for recycling.

The plastic with hazardous symbols is handled as hazardous waste, and is therefore not a part of the recyclables.

The mixed fraction with large items is sorted manually into different fractions at the sorting facility. 
Table 6. Presentation of collected fractions, amounts and setup from Skodsbøl recycling centre in Sønderborg, Denmark (2013 data)

\begin{tabular}{|c|c|c|c|c|c|}
\hline Fractions & Container & $\begin{array}{r}\text { Amounts } \\
\text { [Ton/year] }\end{array}$ & $\begin{array}{l}\text { No. of } \\
\text { visitors } \\
\text { [pers./year] }\end{array}$ & $\begin{array}{l}\text { Amounts per } \\
\text { visitor } \\
\text { [kg/visitor] }\end{array}$ & Reason \\
\hline Buckets (PE) & $\begin{array}{l}\text { Wire mesh } \\
\text { cage }\end{array}$ & 1.28 & $\begin{array}{l}\text { Data } \\
\text { available } \\
\text { later }\end{array}$ & & $\begin{array}{l}\text { Higher selling price for } \\
\text { buckets sorted out in PE } \\
\text { and PET, than for a mix. }\end{array}$ \\
\hline Buckets (PET) & $\begin{array}{l}\text { Wire mesh } \\
\text { cage }\end{array}$ & 0.35 & & & $\begin{array}{l}\text { Higher selling price for } \\
\text { buckets sorted out in PE } \\
\text { and PET, than for a mix. }\end{array}$ \\
\hline $\begin{array}{l}\text { Mixed PP and } \\
\text { PS (flowerpots, } \\
\text { buckets) }\end{array}$ & $\begin{array}{l}\text { Wire mesh } \\
\text { cage }\end{array}$ & 6 & & & $\begin{array}{l}\text { These products might } \\
\text { have been in contact with } \\
\text { soil, and therefor they } \\
\text { need to be washed in a } \\
\text { different way. They should } \\
\text { therefore not be mixed } \\
\text { with the other fractions. }\end{array}$ \\
\hline $\begin{array}{l}\text { Foil (all poly- } \\
\text { mers) }\end{array}$ & $\begin{array}{l}\text { Wire mesh } \\
\text { cage }\end{array}$ & 14 & & & $\begin{array}{l}\text { Several cages placed } \\
\text { strategically around the } \\
\text { centre where the users } \\
\text { can put plastic bags used } \\
\text { for transport. The foil is } \\
\text { not further sorted, but } \\
\text { pressed and sold. Foil is } \\
\text { collected separately since } \\
\text { it has a high price when it } \\
\text { is sorted out. }\end{array}$ \\
\hline Hard PVC & $\begin{array}{l}22 \text { cubic } \\
\text { container }\end{array}$ & 19 & & & $\begin{array}{l}\text { PVC is expensive to } \\
\text { dispose of, therefor } \\
\text { keeping this fraction as } \\
\text { only PVC is important. }\end{array}$ \\
\hline $\begin{array}{l}\text { Large plastic } \\
\text { items (garden } \\
\text { furniture, } \\
\text { buckets larger } \\
\text { than } 5 \text { L, etc.) }\end{array}$ & $\begin{array}{l}22 \text { cubic } \\
\text { container }\end{array}$ & 46 & & & $\begin{array}{l}\text { Garden furniture needs to } \\
\text { be treated specially due to } \\
\text { high chalk content, and it } \\
\text { can contain PVC. }\end{array}$ \\
\hline
\end{tabular}

\section{Selling the fractions and contact with the purchasers}

In Sønderborg, they sort the plastic fractions in a municipally owned sorting facility, which means that the fractions are relatively pure and can be sold at a higher price. Sønderborg Forsyning sells the plastic at the daily market prices instead of making a tender for a longer time period.

This way (and because they have sufficient storage area), they can get better prices, but it requires that they have to have a specific person working with analysing the market and selling the plastic at the right time.

Sønderborg Forsyning has been in dialog with the purchasers and found that when shredding the hard plastic, they should not shred it into smaller pieces than $3 \times 3 \mathrm{~cm}$, otherwise the purchaser cannot sort it fur- 
ther. Sønderborg Forsyning shred the plastic to make the transport more efficient.

\section{Information for users and personnel}

\section{User information at the recycling centre}

- Illustrates what goes where with specific examples. As an example for the PE and the PET, some baskets have been hung on the outside of the wire mesh cages, giving a visual example of what goes where.

- On the signs at the containers, the numbers from the plastic triangle are presented.

\section{User information outside the recycling centre}

- A short guide about the local waste management and the water and energy supply is sent out to all households (in Danish): http://sonfor.dk/ wp-content/uploads/2012/12/Forsyningshaandbog_indhold_ lav_oploesning.pdf

- Every month, there is an article in the local newspaper about a relevant waste topic.

- The municipality is present at relevant events to show specific examples of plastic that can and cannot be recycled.

\section{Information for personnel}

- Four times a year, there is a staff meeting, where relevant topics are discussed. The staff meetings are held outside the normal opening hours of the recycling centre.

- Once a year, the staff goes on a study tour to one of the facilities purchasing the recyclables from the recycling centre. This gives an opportunity for the personnel to get direct feedback from the purchasers and to have experience and knowledge to share with the users.

- External courses for the personnel.

\section{Vestforbrænding - Ballerup genbrugsstation, Denmark}

Vestforbrænding is a public waste company in Denmark covering 19 municipalities in the Copenhagen area. As a specific case, Ballerup recycling centre has been chosen to give an example of some different fractions and a degree of separation in between Göteborg and Sønderborg. 
Ballerup recycling centre is run by the municipality, but transport and agreements with purchasers are handled by Vestforbrænding.

In the area that Ballerup recycling centre is covering, there is also collection of recyclables through a collection of bulky waste at the households, and source separated collection system at household level is in the planning stage.

\section{Fractions collected, containers and why these fractions are selected}

The data presented in Table 7 is based on Ballerup recycling centre, one of the 19 municipalities covered by Vestforbrænding. The separation at the recycling centre consists of five fractions. The plastic is divided into hard plastic and foils due to higher prices on foils. Then there is some additional separation of the hard plastic fractions, which are easy for the user to distinguish between, garden furniture and crates from Arla and Kohberg. ${ }^{14}$ The garden furniture is separated out because the high chalk content makes the density of the plastic different from other hard plastics, which leads to the plastic being rejected in the sorting plant. The crates for Arla and Kohberg are taken back by the producers. Finally, there is a fraction for hard PVC, which can be recycled, but the price for sending the PVC to recycling is high, so to avoid costs it is important to keep the fraction containing PVC as small as possible.

Vestforbrænding has a continued focus on the market prices. If the prices change, this can lead to collection of new / changed fractions.

The plastic with hazardous symbols is handled as hazardous waste, and is therefore not a part of the recyclables.

${ }^{14}$ Crates for milk and bread respectively. 
Table 7. Presentation of collected fractions, amounts and setup from Vestforbrænding recycling centre in Ballerup, Denmark (2013 data)

\begin{tabular}{|c|c|c|c|c|c|}
\hline Fractions & container & $\begin{array}{r}\text { Amounts } \\
\text { [Ton/year] }\end{array}$ & $\begin{array}{r}\text { No. of } \\
\text { visitors } \\
\text { [pers./year] }\end{array}$ & $\begin{array}{r}\text { Amounts per } \\
\text { visitor } \\
{[\mathrm{kg} / \mathrm{visitor}]}\end{array}$ & Reason \\
\hline $\begin{array}{l}\text { Hard plastic } \\
\text { (buckets, toys } \\
\text { w/o metal and } \\
\text { electronics) }\end{array}$ & $\begin{array}{l}30 \text { cubic metre } \\
\text { container }\end{array}$ & 49.8 & 112,016 & 1.57 & \\
\hline Foil & 660 L big bags. & 9.5 & & 0.76 & $\begin{array}{l}\text { Foil is collected } \\
\text { separately, since it } \\
\text { gives a higher } \\
\text { price than the } \\
\text { other fractions. }\end{array}$ \\
\hline Garden furniture & $\begin{array}{l}30 \text { cubic metre } \\
\text { container }\end{array}$ & 9.7 & & 0.63 & $\begin{array}{l}\text { Garden furniture } \\
\text { has high chalk } \\
\text { content. If it is } \\
\text { mixed with the } \\
\text { other plastic } \\
\text { fractions, it will be } \\
\text { rejected and end } \\
\text { up as waste. }\end{array}$ \\
\hline $\begin{array}{l}\text { Arla and Kohberg } \\
\text { crates }\end{array}$ & $\begin{array}{l}\text { Mesh wire } \\
\text { cages deliv- } \\
\text { ered by Aral } \\
\text { (approx. 2-3 } \\
\text { cubic meter) }\end{array}$ & 1.5 & & 0.08 & $\begin{array}{l}\text { Easy to separate } \\
\text { for people. Can go } \\
\text { directly back to } \\
\text { the producers. }\end{array}$ \\
\hline PVC (hard) & $\begin{array}{l}11 \text { cubic meter } \\
\text { container }\end{array}$ & 26.6 & & 1.86 & $\begin{array}{l}\text { PVC is expensive to } \\
\text { get rid of. So to } \\
\text { minimise amounts } \\
\text { of the plastic } \\
\text { fraction containing } \\
\text { PVC, this is collect- } \\
\text { ed separately. }\end{array}$ \\
\hline
\end{tabular}

\section{Information for users and personnel}

\section{User information at the recycling centre}

- At each recycling centre, one of the personnel has been trained to give a guided tour at the recycling centre for e.g. schools explaining about the collection and recycling of the different fractions. Vestforbrænding trains the personnel and provides a kit with the needed material. Besides contributing to the external communication, the information is also meant to be used for the personnel internally.

- Design of the recycling centre in order to assist the user in seeing where to put the different plastic fractions. As an example, plastic fractions that can be mistaken for each other are placed so close, that the users can see the content of both containers, which then helps the user choose the correct container. 
- At Vestforbrænding, they recommend that the pictograms on containers for recyclables and waste are the same at household collection, kerbside collection and recycling centres. Therefore, Vestforbrænding has developed pictograms covering all the waste fractions. The pictograms that are now being tested for plastic are shown in Figure 2.

Figure 2. Pictograms from Vestforbrænding
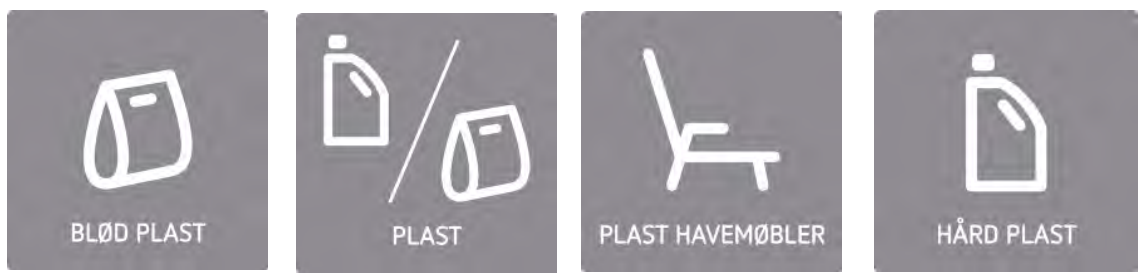

\section{Users information outside the recycling centre}

- Personnel from Vestforbrænding attend public events to inform about their work and recycling in general.

- The municipalities post information about waste collection schemes, including the recycling centres, on their homepages.

\section{Information for personnel}

- A newsletter from Vestforbrænding is sent to the personnel every six weeks with news and information on relevant topics.

- Vestforbrænding has a person visiting the recycling centres to ensure dialog and specific feedback to any questions raised and the actual conditions at the recycling centre. In this way, the dialog between the personnel at the recycling centre and the person from Vestforbrænding can e.g. be based on the actual content of the containers. This gives a more personal contact based on the actual everyday life of the personnel, which is seen as an acknowledgment of the personnel.

- To keep the personnel informed, they are invited to two yearly gatherings, one introducing new actions for the coming year, and the second, a field trip to one of the purchasers or a sorting facility, in order to enhance the understanding of why it is so important to recycle; both with the aim of seeing the great value of their own work effort, but also to be able to tell about it to the users. 
Nordic Council of Ministers

Ved Stranden 18

DK-1061 Copenhagen K

www.norden.org

\section{Plastic sorting at recycling centres}

This report is a background report for the "Guideline for plastic sorting at recycling centres." The background report describes the methodology used in preparing the guideline, including information from existing systems and the stakeholders that can be used by the recycling centres in their decision process. The report describes the importance of communicating with purchasers about the expected purity and traceability of the plastic further down the value chain.

The report is part of the Nordic Prime Ministers' initiative: “The Nordic Region - leading in green growth" - read also more in the web magazine "Green Growth the Nordic Way" at www. nordicway.org
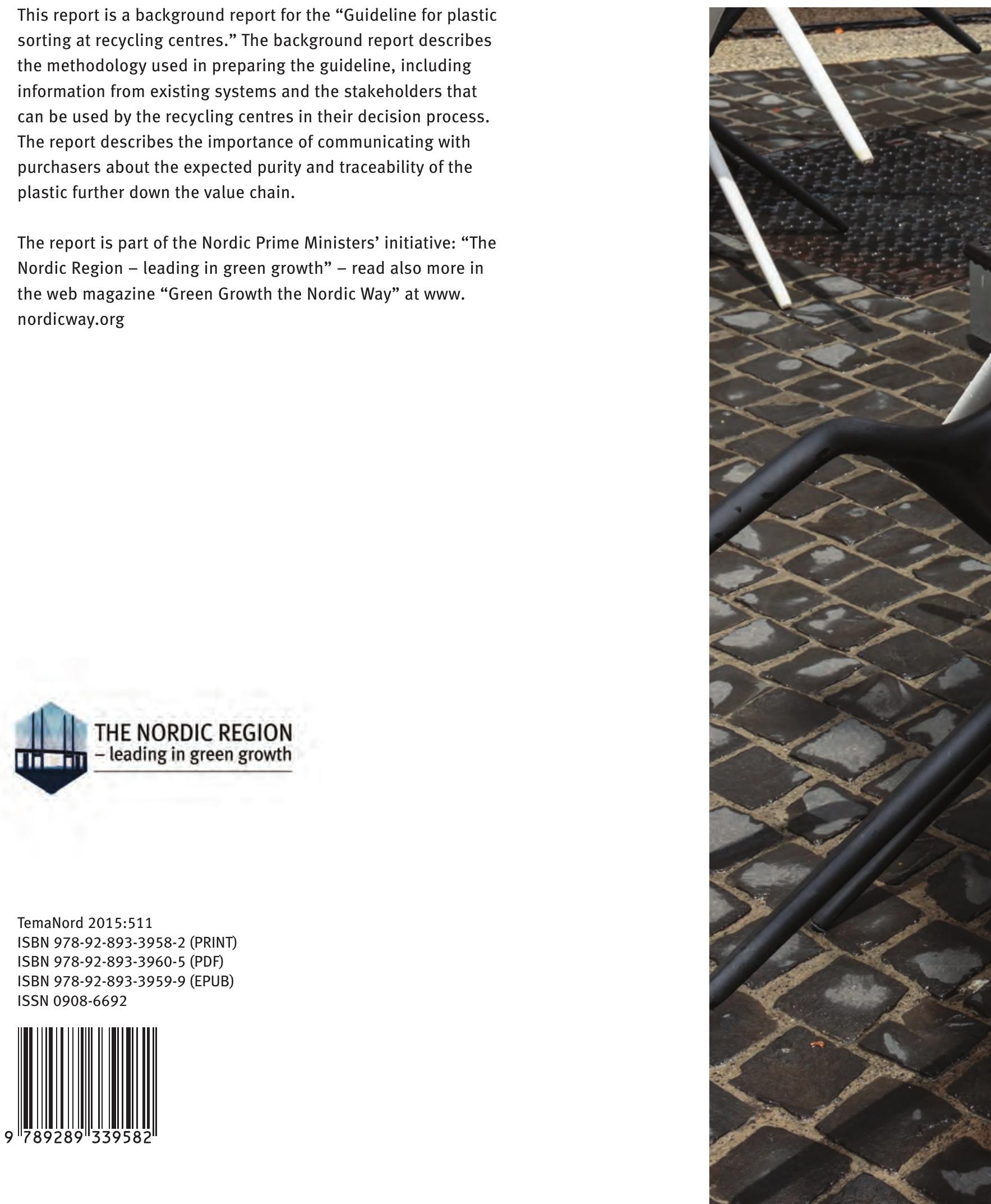